Vol. 2, No. 2, December 2021

DOI: https:// doi.org/10.18196/ijiep.v2i2.13090

\title{
The Relationship Between Religiosity and Sexual Behavior in Adolescents in Merdeka Square, Langsa City.
}

\author{
1Laili Alfita*, ${ }^{1}$ Tisna Catur Ulfa, ${ }^{2}$ Inas Ghalda \\ ${ }^{1}$ Universitas Medan Area, Indonesia \\ ${ }^{2}$ Universitas Zaitunah, Tunisia
}

*Corresponding email: alfitalaiali@gmail.com

\section{ARTICLE INFO}

Article History

Received : 10/11/2021

Revised : 16/11/2021

20/11/2021

$01 / 12 / 2021$

$17 / 12 / 2021$

$23 / 12 / 2021$

Accepted: 23/12/2021

\section{Keywords}

Relationship, Religiosity, Sexual Behavior,

Adolescents, Educational

Psychology

\begin{abstract}
This study aims to determine the relationship between religiosity and sexual behavior in dating adolescents in Merdeka Square, Langsa City. The research focuses on the relationship between religiosity and sexual behavior. The method used in this research was the quantitative correlation method. The research sample was teenagers dating in Merdeka Square, Langsa City, as many as 40 couples aged 17-21 years. The scale employed was a Likert scale model and the semantic differential. The sampling technique used accidental sampling. Data analysis employed the Product Moment correlation method from Karl Pearson. The study results revealed a significant relationship between religiosity and sexual behavior. The reliability of the religiosity scale $\mathrm{rbt}=0.898$, and the reliability of the sexual behavior scale $\mathrm{rbt}=0.968$. The data analysis technique used was the Product Moment correlation technique, utilizing SPSS version 18.0. Based on data analysis, it was found that a significant positive relationship between religiosity and sexual behavior in dating adolescents in Merdeka Square, Langsa City. It was indicated by the coefficient $\mathrm{rxy}=0.401$ with $\mathrm{p}(0.000)<0.010$. The hypothetical results obtained from this study are that religiosity was classified as low with a hypothetical mean value of 80 and an empirical mean value of 93.19, while sexual behavior was classified as high with a hypothetical mean value of 136 and an empirical mean value of 139.79 . From the results of this study, religiosity contributes to sexual behavior by $16.1 \%$, so that the proposed hypothesis was accepted.
\end{abstract}

This is an open access article under the CC BY-SA license.

\section{Citation:}

Alfita, L., Ulfa, T. C., \& Ghalda, I. (2021). The relationship between religiosity and sexual behavior in adolescents in Merdeka Square, Langsa City. International Journal of Islamic Educational Psychology, 2(2), 167-176. DOI: https:// doi.org/10.18196/ijiep.v2i2.13090 
Alfita, Ulfa \& Ghalda | The Relationship Between Religiosity and Sexual Behavior in Adolescents in Merdeka Square, Langsa City.

\section{INTRODUCTION}

Sexual behavior is an activity carried out based on sexual urges or activities to obtain satisfaction in the sexual organs through forms of sexual behavior. Sarwono (2010) revealed that sexual behavior is driven by sexual desire, both with the opposite sex and the same sex. Abraham (1999) also explained that the concept of sexuality includes not only sexual identity, sexual orientation, sexual norms, sexual practices, and sexual habits, but also human feelings, desires, fantasies, and experiences related to sexual awareness, stimulation, and sexual acts, including heterosexual, and homosexual relationships (Muwaga, et al., 2020). It includes subjective experience and the meaning attached to it. The concept of sexuality comprises not only the biological and psychological but also the social and cultural dimensions of sexual identity and habits.

Based on the survey results of the National Population and Family Planning Agency or Badan Kependudukan dan Keluarga Berencana Nasional (BKKBN) in major cities in Indonesia, it was shown that the incidence of premarital sex reached 54\% in Surabaya, $47 \%$ in Bandung, and 52\% in Medan. Around 51\% of adolescents were no longer virgins in the Greater Jakarta area. Also, 4\% of respondents claimed to have had sexual intercourse since the age of 16-18 years, and $16 \%$ had committed at the age of $13-15$ years (BKKBN, 2010). In addition, a case reported by News Detik.com on March 13, 2014, reported that the Aceh Islamic Sharia Police arrested two young women who claimed to be Lesbians in Deah Lamglumpang Village, Meuraxa Sub-district, Banda Aceh City.

Kuncoro (2015) wrote that in 2014, adolescents aged 10-24 years were around 64 million or $28.6 \%$ of Indonesia's population of 222 million. Of that number, 21 million Indonesian teenagers have had sex. $62.7 \%$ of students have had sexual intercourse. $21.2 \%$ of students have had an abortion. $93.7 \%$ have kissed, done genital stimulation, and oral sex. 97\% have watched porn. Meanwhile, in Yulianto's (2010) research, it was revealed that 59.3\% of male adolescents were affected by pornographic books and $48.8 \%$ of pornographic films. Meanwhile, for young women, $28.4 \%$ were affected by pornographic books, and $15.9 \%$ of pornographic films.

Quoted from Bangkapos.Com, in Langsa, March 03, 2019, at 01.30 WIB, Langsa City Islamic Sharia officers and the Wilayatul Hisbah Police (WH) (Muhammad, 2017) raided and arrested the perpetrators of the lewd act at the former East Aceh Regency Education Office, which is located on Jalan Ahmad Yani, Langsa. The arrest was initiated by a WH officer patrol at the former office, and at that time, a number of teenagers were seen in pairs committing lewdness, both inside, and outside the building. Some of the teenagers were successfully arrested, and several others escaped from being chased by officers. The officers managed to arrest three people; it should have been four people or two couples, but one man managed to escape when ambushed so that the three teenagers were immediately taken to the office of the Langsa City Islamic Shari'a Service. The teenager who was arrested was 18 years old, and his partner was aged 17, both residents of 
Alfita, Ulfa \& Ghalda | The Relationship Between Religiosity and Sexual Behavior in Adolescents in Merdeka Square, Langsa City.

Langsa City. One of the teenagers admitted that they had carried out lewd practices in various ways, but they had not done it like a husband-and-wife relationship. They did that not only when they were in the empty building but also in various places, such as internet cafes. In addition, these teenagers also said that they often stayed up late and slept together in various places. Meanwhile, a 17-year-old female perpetrator, a resident of Langsa, also admitted that she and her partner often committed lewd acts at the former East Aceh Education Office.

These sexual behaviors certainly have a bad impact on teenagers. Darroch et al. (2001) revealed that sexually transmitted diseases, which are now called sexually transmitted infections (STDs), are diseases spread through sexual activity. STDs in adolescent girls tend to develop almost undetected in a single, unprotected sexual activity with an infected partner; adolescent girls have a $1 \%$ risk of getting $\mathrm{HIV}$, a $30 \%$ risk of getting genital herpes, and a 50\% risk of gonorrhea. Papalia (2009) uncovered that adolescents tend to have oral sex, which has a lower risk than copulation, even though many STDs, especially pharyngeal gonorrhea, can be transmitted this way. Duvall \& Miller (1985) described forms of sexual behavior, including holding hands, dry kissing, wet kissing, hugging, fantasizing, imagining, fingering, masturbating, and petting.

In their research, Firdaus and Ningsih (2020) described that subjects with high religiosity were 54 people $(41.5 \%)$, while subjects with sexual behavior were in the moderate category as many as 45 people $(34.7 \%)$. It means that, in general, the subjects in their study tended to have moderate levels of sexual behavior. Therefore, in the study, religiosity was higher than sexual behavior, as seen from the value of $p=0.017(p<0.05)$. It signifies a relationship between religiosity and sexual behavior in dating adolescents in Padang City.

Moreover, Yuliva et al. (2020) research analyzed data univariately and bivariate with a chi-square statistical test. In the univariate analysis, it was found that $54.1 \%$ of respondents had risky sexual behavior, $45.9 \%$ had low religiosity, $36.5 \%$ had authoritarian parenting, and $54.1 \%$ of peers played a role in sexual behavior. Meanwhile, the bivariate analysis results for the relationship of religiosity obtained $p$-value $=0.001(p<0.05)$, the relationship of parenting obtained $p$-value $=0.000(p<0.005)$, and the role of peers obtained $p$-value $=0.026(p<0.005)$ with sexual behavior in adolescents.

Based on this, the hypothesis was obtained that there was a negative relationship between religiosity and sexual behavior in adolescents. It is with the assumption that the lower the religiosity, the higher the sexual behavior in adolescents (Muwaga et al., 2020). Conversely, the higher the religiosity, the lower the sexual behavior in adolescents.

Several previous studies described above show that the religiosity variable can help reduce juvenile delinquency, especially in sexual behavior. Also, given that the problem of adolescent sexual behavior is becoming increasingly worrisome, this issue needs to be raised, and a solution found. One of them is conducting 
Alfita, Ulfa \& Ghalda | The Relationship Between Religiosity and Sexual Behavior in Adolescents in Merdeka Square, Langsa City.

research related to what can reduce adolescent sexual behavior. Therefore, the authors believe that this research is very urgent to be carried out.

\section{METHODS}

This type of research was quantitative correlational, where correlation research aims to find out whether there is a relationship, how close the relationship is, and whether the relationship is meaningful. It also aims to determine the correlation of two variables: the independent and the dependent variables, by knowing the extent to which the independent variable, namely religiosity, is related to the dependent variable, sexual behavior. This research was conducted on teenagers dating in Merdeka Square, Langsa City.

According to Sugiyono (2003), the population is a generalization area consisting of objects or subjects that become certain quantities and characteristics determined by researchers to be studied and then drawn conclusions. In this study, the population used were teenagers in Merdeka Square, Langsa City. Then, the sampling technique used was accidental sampling. Sugiyono (2010) explains accidental sampling as a sampling technique based on chance, namely that respondents who coincidentally/incidentally meet with researchers can be used as samples if it is deemed that the person who happened to be met is suitable for a candidate data source. The samples taken for this study were 40 pairs of teenagers aged 17-21 years dating at Merdeka Square, Langsa City.

In this study, collecting quantitative data used a Likert scale model and the semantic differential. The religiosity scale model employed in this study was the Likert scale. Through Glock and Stark (1965) the dimensions consisted of religious practice, religious belief, religious knowledge, religious effect, and religious feeling.

The scale value of each question was obtained from the subject's answers stating they supported (favorable) or did not support (unfavorable) each statement in four categories of answers: "Highly Suitable (SS)", "Suitable (S)", "Unsuitable (TS)", "Highly Unsuitable (STS)". The value of the favorable items moved from a score of four for the "SS" answer, three for the "S" answer, two for the "TS" answer, and one for the "STS" answer. On the other hand, the assessment of unfavorable items moved from a value of one for "SS", two for an "S" answer, three for a "TS" answer, four for an "STS" answer.

Meanwhile, sexual behavior is based on Duvall \& Miller (1985) that forms of adolescent sexual behavior include holding hands, dry kissing, wet kissing, hugging, fantasizing or imagining, fingering, masturbating, and petting, utilizing a semantic differential scale in this study. The semantic differential scale measures attitudes, arranged on a continuum, where a very positive answer lies on the right side of the line, whereas a very negative answer lies on the left side of the line, or vice versa. The semantic differential scale contains a series of bipolar (two-pole) characteristics. The data obtained through measurements with 
Alfita, Ulfa \& Ghalda | The Relationship Between Religiosity and Sexual Behavior in Adolescents in Merdeka Square, Langsa City.

a semantic differential scale are data intervals from 1 to 7 , with strongly agree and strongly disagree.

\section{RESULTS}

Data analysis obtained a significant positive relationship between religiosity and sexual behavior in dating adolescents in Merdeka Square, Langsa City. It was indicated by the coefficient rxy $=0.401$ with $\mathrm{p}(0.000)<0.010$. In addition, from the calculation of $\mathrm{r}$ Product Moment Analysis, the effective contribution of $\mathrm{X}$ to $\mathrm{Y}$ was $16.1 \%$. To determine the condition of religiosity and sexual behavior, it was necessary to compare the empirical mean with the hypothetical mean, taking into account the SD of each variable, as illustrated in the table below:

Table. 1 Comparison of the Empirical Mean and Hypothetical Mean

\begin{tabular}{|c|c|c|c|c|}
\hline \multirow{2}{*}{ Variable } & \multirow{2}{*}{ SD } & \multicolumn{2}{|c|}{ Mean Score } & \multirow{2}{*}{ Description } \\
\cline { 3 - 4 } & & Hypothetical & Empirical & \\
\hline Religiosity & 13.303 & 80 & 93.19 & Low \\
\hline Sexual behavior & 50.712 & 136 & 139.79 & High \\
\hline
\end{tabular}

Based on the hypothetical and empirical mean, the data analysis results describe the relationship between religiosity and sexual behavior, with low religiosity $=$ 93.19 and high sexual behavior $=139.79$. It denotes that dating teenagers can engage in sexual behavior due to a lack of knowledge of religious values in a kaffah manner so that sexual behavior occurs; in this case, religiosity is guiding or directing each individual.

Likewise, the determinant coefficient R-Square $\left(R^{2}\right)$ of the relationship between the independent variable $X$ and the dependent variable $Y$, as shown in the table below, shows that R-Square $\left(\mathrm{R}^{2}\right)=0.161$. It signifies that religiosity contributed to sexual behavior by $16.1 \%$. Meanwhile, the other $89.3 \%$ were influenced by several factors of sexual behavior, including biological factors, parental influence, peer influence, academics, understanding of social life, sexual experience, understanding, and appreciation of religious values, personality factors such as self-esteem, and knowledge about reproductive health. The above description is summarized in the table below:

Table. 2. Determinant Coefficient (R-Square)

\begin{tabular}{|c|c|c|c|c|c|}
\hline Statistics & $\begin{array}{c}\text { Coefficient } \\
\left(\mathbf{R}_{\mathbf{x y}}\right)\end{array}$ & $\begin{array}{c}\text { Determinant } \\
\text { Coefficient } \mathbf{( R}^{\mathbf{2}} \mathbf{)}\end{array}$ & $\mathbf{B E} \%$ & $\mathbf{P}$ & Description \\
\hline $\mathrm{X}-\mathrm{Y}$ & 0.401 & 0.161 & $16.1 \%$ & 0.000 & Significant \\
\hline
\end{tabular}

It aligns with Rosidah's (2012) research, which found a correlation between selfesteem and premarital sexual behavior of -0.269 with a significance of 0.001 . It means a very significant negative relationship between self-esteem and adolescent premarital sexual behavior. Meanwhile, the correlation value between religiosity and premarital sexual behavior was -0.471 with a significance of 0.000 , 
Alfita, Ulfa \& Ghalda | The Relationship Between Religiosity and Sexual Behavior in Adolescents in Merdeka Square, Langsa City.

meaning a very significant negative relationship between religiosity and adolescent premarital sexual behavior. In the F-test, the value of F-count was $21.915>$ F-table of 4.771 , with a p-value of $0.000<0.01$. It shows that self-esteem and religiosity could be used to measure adolescent premarital sexual behavior. The data analysis results also uncovered the value of R-Square $\left(\mathrm{R}^{2}\right)$ of 0.255 . It denotes that in the study, self-esteem, and religiosity contributed $25.5 \%$ to premarital sexual behavior, with each variable contributing $4.97 \%$ for the selfesteem variable and $20.53 \%$ for the religiosity variable.

In addition, in the research of Husaini and Mariyanti (2016) the results of the Pearson product-moment correlation test obtained a value (sig=0.013, $\mathrm{p}<0.05)$, with a correlation coefficient value $(r)=-0.247$. It signifies a significant negative relationship between religiosity and premarital sexual behavior. Religiosity contributed $6.1 \%$ to premarital sexual behavior. Then, it was found that gender, family status, and length of dating were not related to premarital sexual behavior. The dominant sexual behavior in Esa Unggul University students was oral sex.

Hafiz (2019) also revealed in his research on religiosity and morality: the theory of God's punishment to increase the role of religion in morality concluded that God's punishment might be negatively correlated with a person. However, it does not mean that it causes pathological problems for religious people; a person's religious orientation might greatly influence the impact of God's punishment on self and behavior.

Likewise, Aridhona (2018) research explained that the effect of prosocial behavior and religiosity on morals was $51.1 \%$, while other variables influenced the rest. On the other hand, Rifai (2021) revealed, based on his research's results, that high religiosity with moral anxiety was 0.544 , indicating that there was a significant correlation between the level of religiosity and moral anxiety. Meanwhile, from the results of his research, Firmansyah (2020) found that teachers and parents had various ways of developing youth religiosity and moral behavior, such as supervising, setting examples, providing good habits, and inserting lectures in subjects. Therefore, it can be seen that religiosity is very influential on sexual behavior.

\section{DISCUSSION}

Table I below summarizes the calculation results of the $\mathrm{R}$ Product Moment analysis. Meanwhile, the explanation is that the determinant coefficient $\left(R^{2}\right)$ of the relationship between the independent variable $X$ and the dependent variable $\mathrm{Y}$ was $=0.161$. It shows that religiosity contributed to sexual behavior by $16.1 \%$. 
Alfita, Ulfa \& Ghalda | The Relationship Between Religiosity and Sexual Behavior in Adolescents in Merdeka Square, Langsa City.

Table 3. Calculation Results of R Product Moment Analysis

\begin{tabular}{|c|c|c|c|c|c|}
\hline $\begin{array}{c}\text { Statistic } \\
\mathbf{s}\end{array}$ & $\begin{array}{c}\text { Coefficient } \\
(\mathbf{R x y})\end{array}$ & $\begin{array}{c}\text { Determinant } \\
\text { Coefficient (R } \mathbf{R}^{2}\end{array}$ & $\mathbf{B E} \%$ & $\mathbf{P}$ & Description \\
\hline $\mathrm{X}-\mathrm{Y}$ & 0.401 & 0.161 & $16.1 \%$ & 0.000 & Significant \\
\hline
\end{tabular}

Description:

$\mathrm{X} \quad=$ Religiosity

$\mathrm{Y} \quad=$ Sexual behavior

$\mathrm{Rxy} \quad=$ The coefficient of the relationship between $\mathrm{X}$ and $\mathrm{Y}$

$\mathrm{R}^{2} \quad=$ The coefficient of determinant $X$ against $\mathrm{Y}$

$\mathrm{P} \quad=$ Significance

$\mathrm{BE} \%=$ The weight of the effective contribution of $\mathrm{X}$ against $\mathrm{Y}$ in percent

Ket = Significance

Table 4. Calculation Results of the Hypothetical Mean and Empirical Mean

\begin{tabular}{|c|c|c|c|c|}
\hline \multirow{2}{*}{ Variable } & \multirow{2}{*}{ SD } & \multicolumn{2}{|c|}{ Mean Score } & \multirow{2}{*}{ Description } \\
\cline { 3 - 4 } & & Hypothetical & Empirical & \\
\hline Religiosity & 13.303 & 80 & 93.19 & Low \\
\hline Sexual behavior & 50.712 & 136 & 139.79 & High \\
\hline
\end{tabular}

Meanwhile, the explanation of the hypothetical and empirical tables is as follows:

a. Hypothetical Mean

For the religiosity variable, the number of valid items was 32, which were formatted with a Likert scale in four answer choices so that the hypothetical mean was $(32 \times 1)+(32 \times 4): 2=80$.

Meanwhile, for the sexual behavior variable, the number of valid items was 34 , which were formatted with a differential semantic scale in seven answer choices so that the hypothetical mean was $(34 \times 1)+(34 \times 7): 2=136$.

b. Empirical Mean

Based on the data analysis, as seen from the descriptive correlation analysis, it is known that the empirical mean of the religiosity variable was 93.19, while for the sexual behavior variable, the empirical mean was 139.79.

c. Criteria

To determine the condition of religiosity and sexual behavior, it was necessary to compare the empirical mean with the hypothetical mean, considering the magnitude of the SD value of each variable. For the religiosity variable, the SD value was 13.303 , while for the sexual behavior variable, the SD value was 50.712 .

Therefore, it can be seen that, in the table, the hypothetical mean < empirical mean, which was obtained from the hypothetical mean minus SD, and the empirical mean was below it, so religiosity was low. 
Alfita, Ulfa \& Ghalda | The Relationship Between Religiosity and Sexual Behavior in Adolescents in Merdeka Square, Langsa City.

Furthermore, for the sexual behavior variable, it can be seen that the hypothetical mean < empirical mean, which was obtained from the hypothetical mean plus $\mathrm{SD}$, and the empirical mean was above it, so sexual behavior was classified as high/good.

Based on the results obtained in this study, the relationship between religiosity and sexual behavior in adolescents in Merdeka Square, Langsa City, can be concluded as follows. There was a relationship between religiosity and sexual behavior (Grubbs et al., 2020). The lower the religiosity, the higher the sexual behavior (Zilberman et al., 2018). Thus, the hypothesis proposed in this study was declared accepted. Furthermore, by looking at the empirical and hypothetical mean values, it can be concluded that the accepted religiosity was low, while the accepted sexual behavior was high.

Based on the research results above, the researchers suggest that teenagers, especially those who have had relationships related to sexual behavior, should try to be busier with other pleasant things, such as following studies that lead to good things, or it could be by joining youth associations who have a hobby of sports, helping people in need, and other good things; hence, sexual behavior can be avoided as much as possible (McKibbin et al., 2017). The recommendation for practical implications and policy making can be improvement and systematizing parental training in children sexuality education; expanding training approaches to encourage active parenting and promote parent-child communication skills as the essentials in sexually-related nurturing and caring of children (MerghatiKhoei et al., 2019).

Likewise, for Wilayatul Hisba, it is recommended to control the activities carried out by teenagers more often, especially in Merdeka Square and its surroundings, so that events that have occurred in the past will not be repeated, and if it is also possible to make or suggest to those responsible for making activities that can be attended by teenagers who need direction to become better teenagers in the future.

\section{CONCLUSIONS}

Parents and families should be able to control better the intercommunication of children who still need direction and guidance. Also, parents should be able to emphasize to children the rules that must be obeyed, such as not going out too late, introducing friends, telling what was done that day, and being able to explain the good and bad things that can and cannot be done, so that children can better understand and avoid unwanted things, such as engaging in sexual behavior outside of marriage.

Also, educational institutions could provide more lessons that explain religion or beliefs that must be adhered to and what should not be done so that students/teenagers who do not really understand can become more understanding and stay away from sexual behavior or other bad behaviors. It is also necessary if the Indonesian Child Protection Commission KPAI can play a 
Alfita, Ulfa \& Ghalda | The Relationship Between Religiosity and Sexual Behavior in Adolescents in Merdeka Square, Langsa City.

more role in taking firm action against sexual behavior or bad behavior committed by teenagers all over so that pregnancies out of wedlock or underage marriages do not occur, which can worsen future generations.

Meanwhile, future researchers may expand the research population further and try to use other methods, such as qualitative, to deepen the problem of religiosity and sexual behavior.

\section{REFERENCES}

Abraham, L., \& Kumar, K. A. (1999). Sexual experiences and their correlates among college students in Mumbai City, India. The Indian Journal of Social Work, 62(2), 139-152.

Aridhona, J. (2018). Hubungan prilaku prososial dan religiusitas dengan moral $\begin{array}{llll}\text { pada remaja. Jurnal Konselor, } & \text { 7(1), }\end{array}$ https://doi.org/10.24176/perseptual.v2i1.2218

Darroch, J.E., Frost, J.J. \& Singh, S. (2001). Teenage sexual and reproductive behavior in develop countries: Can more progress be made? New York: Allan Guttmacher Institute.

Duvall, E. M \& Miller, C. M. (1985). Marriage and family development (6th Ed). New York: Harper \& Row Publisher.

El Hafiz, S. (2020). Religiusitas dan moralitas: Teori hukuman tuhan untuk meningkatkan peran agama dalam moralitas. Jurnal Ilmiah Penelitian Psikologi: Kajian Empiris \& Non-Empiris, 5(2), 105-112. https:// doi.org/10.22236/JIPP-62

Firdaus, V. \& Ningsih, Y. T. (2020) Hubungan religiusitas dengan prilaku seksual pada remaja yang berpacaran di Kota Padang. Jurnal Riset Psikologi, 2020(2), 1-11. http://dx.doi.org/10.24036/jrp.v2020i2.8651

Firmansyah, F. A. A. (2020). Peran orang tua dan guru untuk mengembangkan prilaku moral dan religiusitas remaja. Prophetic: Propesional. Empathy and Islamic Counseling Journal, 3(12), 177-186. http://dx.doi.org/10.24235/prophetic.v3i2.7593

Glock, C. Y., \& Stark, R. (1965). Religion and society in tension. Chicago: Rand McNally.

Grubbs, J. B., Kraus, S. W., Perry, S. L., Lewczuk, K., \& Gola, M. (2020). Moral incongruence and compulsive sexual behavior: Results from cross-sectional 
Alfita, Ulfa \& Ghalda | The Relationship Between Religiosity and Sexual Behavior in Adolescents in Merdeka Square, Langsa City.

interactions and parallel growth curve analyses. Journal of abnormal psychology, 129(3), 266-278. https://doi.org/10.1037/abn0000501

Husaini, I., \& Mariyanti, S. (2016). Hubungan antara religiusitas islam dan perilaku seksual pranikah pada mahasiswa Universitas Esa Unggul tahun ajaran 2015/2016. Jurnal Psikologi Media Ilmiah Psikologi, 14(2), 44-52.

Kirana, H. (2015). Gambaran perilaku seks pranikah mahasiswa Universitas Indonesia angkatan 2014-2015. Depok: FKM UI.

Kuncoro, K. (Presenter). (2015, Juni 10). Interview with Kritaya (TAWA). In TAWA [Radio Broadcast]. Radio KPFM 96,8 FM Samarinda.

McKibbin, G., Humphreys, C., \& Hamilton, B. (2017). "Talking about child sexual abuse would have helped me": Young people who sexually abused reflect on preventing harmful sexual behavior. Child abuse $\mathcal{E}$ neglect, 70, 210-221. https:// doi.org/10.1016/j.chiabu.2017.06.017

Merghati-Khoei, E., Atoof, F., Sheikhan, F., Omati, S., Aghajani, N., \& Hosseinzadeh, M. (2019). Assessing Iranians' parental competence: Development and psychometric properties of the Children's Sexual Behavior Questionnaire (CSBQ-IR), Iranian Version. Health promotion perspectives, 9(2), 131-136. https:// doi.org/10.15171/hpp.2019.18

Muhammad, R. A. (2017). The role of wilayat al-hisbah in the implementation of islamic shariah in Aceh. Petita: Jurnal Kajian Ilmu Hukum dan Syariah, 2(2), 124-133. https:/ / doi.org/10.22373/ petita.v2i2.64

Muwaga, M., Nashori, F., \& Sholeh, A. (2020). The impact of social environment on the sexual self-regulation of University Students in Uganda. International Journal of Islamic Educational Psychology, 1(2), 75-88. https:// doi.org/10.18196/ijiep.v1i2.10011

Papalia, D. E., Olds, S. W., dan Feldman, R. D. (2009). Human development (eleventh edition). New York: McGraw-Hill.

Rifai, R. (2021) Hubungan tingkat religiusitas terhadap kecemasan moral dan alternatif pembinaan moral pada kenakalan siswa. Jurnal Teologi Gracia Deo, 3(2), 76-87. https:// doi.org/10.46929/graciadeo.v3i2.63

Rosidah, A. (2012). Religiusitas, harga diri dan prilaku seksual pranikah remaja. Jurnal Psikologi Tabularasa, 7(2), 585-593.

Sarwono. S.W. 2010. Psikologi remaja. Jakarta: Raja Grafindo Persada. 
Alfita, Ulfa \& Ghalda | The Relationship Between Religiosity and Sexual Behavior in Adolescents in Merdeka Square, Langsa City.

Sugiyono, S. (2003). Metode penelitian. Bandung: Alfabeta.

Sugiyono, S. (2010). Metode penelitian, kuantitatif, kualitatif, dan RED. Alfabeta Bandung.

Yulianto, Y. (2010). Gambaran sikap siswa smp terhadap perilaku seksual pranikah (penelitian dilakukan di SMPN 159 Jakarta). Jurnal Psikologi Volume 8(2), 46-58.

Yuliva, Y., Yusevni, E., \& Azian, V. (2020). Faktor-faktor yang berhubungan dengan perilaku seksual pada remaja di Kota Painan. Jurnal Sehat Mandiri, 15(2), 119-133. https:/ / doi.org/10.33761/jsm.v15i2.318

Zilberman, N., Yadid, G., Efrati, Y., Neumark, Y., \& Rassovsky, Y. (2018). Personality profiles of substance and behavioral addictions. Addictive behaviors, 82, 174-181. https://doi.org/10.1016/j.addbeh.2018.03.007 